\title{
Preliminary Prediction of Rice Planting for Planting Season 2019, 2020, and 2021, Based Water Balance in Freshwater Swampland
}

\author{
Vika Mayasari ${ }^{*}$ and Anna Hairani ${ }^{1}$ \\ ${ }^{1}$ Indonesian Swampland Agricultural Research Institute(ISARI), Banjarbaru, Kalimantan Selatan
}

\begin{abstract}
Climate change that has occurred in recent years causes a shift at the beginning of rice planting. Rice crop failure due to flooding or drought is the main cause of the low Cropping Index in the freshwater swampland such as happened in Swampland Agro Science Park of Banjarbaru. Therefore, this study was carried out to determine the preliminary prediction of the rice planting season for planting season (MT) 2019, 2020, and 2021 based on water balance. As for what can be analyzed was the rainfall data as input compared to evapotranspiration through the Hargreaves approach. Then the output obtained in the form of net rate which used to measure the amount of rain every year. Meanwhile, the water requirement for rice was calculated during the period of growth to harvest. After that, the water balance simulation was performed from the difference in water bubbles (net yield rate) with the water needs in the rice field. Based on this water balance simulation obtained that the beginning of rice planting for MT 2019 is May IV-June IV, MT 2020 is June I-July I, and MT 2021 is June II-July II.
\end{abstract}

\section{Introduction}

There are three growing seasons (MT) in Indonesia, namely: (a) MT-I or rainy season (MH), November to February; (b) MT-II or first dry season (MK-I), also called Gadu season, March to June; and (c) MT III or second dry season (MK-II), July to October. However, due climatic anomalies such as the drought period (El Nino year) and /or wetness (La Nina year), it causes a shift in the beginning and the end of the growing season so that it has negative impacts on crop productivity, especially rice [1].

South Kalimantan has a flat topography but still has mountainous areas, valleys, which lie between the Java Sea and the Makassar Strait, resulting in the emergence of complex climatic conditions. This causes a shift at the beginning of the growing season, especially for rice [2].

According to the most recent data [3], it is estimated that the total area of swampland in Indonesia is 34,93 million ha consisting of peatlands and mineral lands. From those areas, about 10.87 million ha consisting of 2.34 million ha freshwater swampland and 8.54 million ha tidal swampland is suitable for agriculture. Freshwater swampland consists of three typologies, i.e. shallow freshwater swampland (water depth $<50 \mathrm{~cm}$ ), medium freshwater swampland (water depth 50-100 cm), and deep freshwater swampland (water depth> $100 \mathrm{~cm}$ ) with inundation time at least three months. Freshwater swampland has an average planting index of 100 or can only be planted once with moderate soil fertility since nutrient supply from overflowing rivers [4]. This indicates the big potential of the freshwater swampland to be developed as barn food by adjusting the appropriate time of planting.

Failure of planting to harvest failure is the main problem that occurs in Swampland Agro Science Park of Banjarbaru (TSPLR) due to a mistaking in starting planting time. Therefore, predicting the beginning of rice planting in TSPLR for MT 2019, 2020, and 2021 subject to climate anomalies needs to be studied.

\section{Materials and Methods}

\subsection{Research sites and time}

The research was located in 5 ha of freshwater swampland at Swampland Agro Science Park of Banjarbaru at $3^{\circ} 26^{\prime} 9.38$ "latitude and $114^{\circ} 47^{\prime} 47.66^{\prime \prime}$ east longitude (Fig. 1). The study was conducted for 12 months from January to April 2019. The observation is being in progress until for the next two years.

\subsection{Data collection}

Hydroclimatological data such as rainfall, temperature, and humidity were obtained from Syamsuddin Noor Banjarmasin Meteorological Station. Rainfall data was further processed into an analysis of daily rainfall fluctuations over the past 30 years. Meanwhile, data of maximum and minimum temperature, average temperature, and average relative humidity were used for the calculation of evapotranspiration.

\subsection{Evapotranspiration}

Evapotranspiration was calculated using the Hargreaves method. The ET0 value was calculated based on air temperature data measured continuously by temperature and humidity sensors at the study site. The formulation [5] is as follows:

Corresponding author : vikamaya.balittra@gmail.com 


$$
\begin{array}{r}
\mathrm{ET}_{0}=0.000938 \mathrm{R}_{\mathrm{a}}\left(\mathrm{T}_{\max }-\mathrm{T}_{\min }\right){ }^{0.5}\left(\mathrm{~T}_{\text {Average }}+17.8\right) \\
\mathrm{R}_{0}: \text { Extraterrestrial radiation }\left(\mathrm{MJ} \mathrm{m}^{-2} \mathrm{~h}^{-1}\right) \\
\mathrm{T}_{\text {max }}: \text { Maximum daily temperature }\left({ }^{\circ} \mathrm{C}\right) \\
\mathrm{T}_{\min }: \text { Minimum daily temperature }\left({ }^{\circ} \mathrm{C}\right) \\
\mathrm{T}_{\text {average }}: \text { Average daily temperature }\left({ }^{\circ} \mathrm{C}\right)
\end{array}
$$

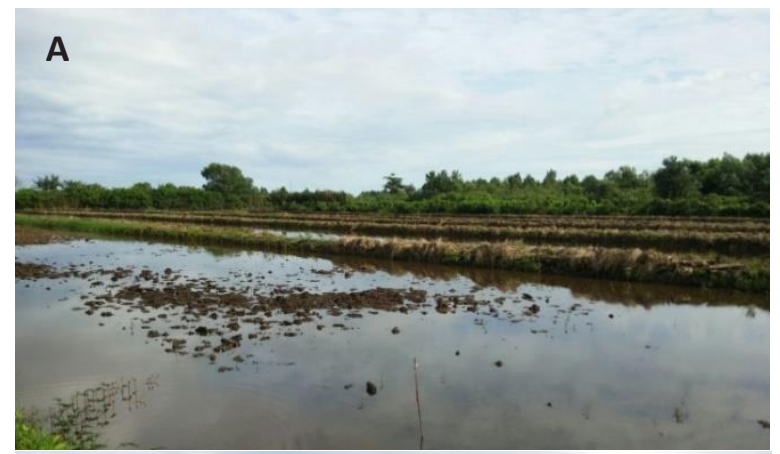

B

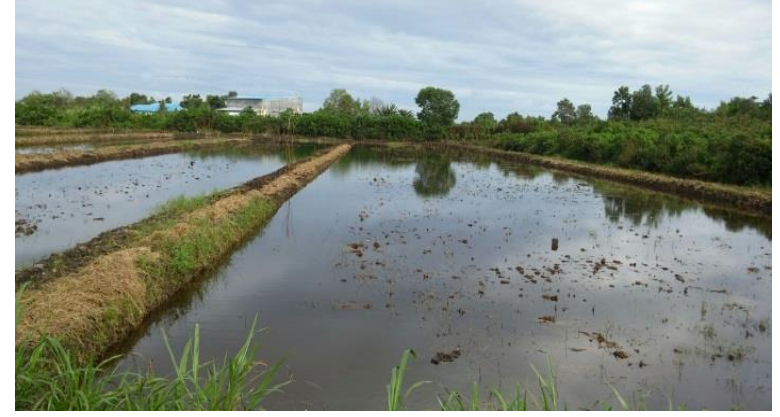

Figure1. Research site at Swampland Agro Science Park of Banjarbaru (A) and (B)

\subsection{Water Balance (Net Rate)}

The water balance is based on the law of conservation of mass, where any change in groundwater content for a range of time must be the same as the difference between the amount of water added to the soil and the amount of water coming out of the soil. The remaining water is usually called the net rate.

$\Delta \theta$ : Changes in volumetric soil water content $\left(\mathrm{cm}^{3} \mathrm{~cm}^{-3}\right)$;

$\Delta \mathrm{h}$ : Changes in water depth equivalent $(\mathrm{mm})$;

$\Delta \mathrm{t}$ : Time interval (h).

$\mathrm{Z}$ : Depth of plant rhizosphere (mm);

$\mathrm{r}$ : Rain intensity, rainfall $\left(\mathrm{mm} \mathrm{h}^{-1}\right)$,

et: Evapotranspiration rate, evapotranspiration $\left(\mathrm{mm} \mathrm{h}^{-1}\right)$, ro: runoff rate, run-off $\left(\mathrm{mm} \mathrm{h}^{-1}\right)$,

GW: Capillarity rate of groundwater, groundwater $\left(\mathrm{mm} \mathrm{h}^{-1}\right)$, $\mathrm{dp}$ : Percolation rate, deep percolation $\left(\mathrm{mm} \mathrm{h}^{-1}\right)$, qi: Irrigation rate, irrigation $\left(\mathrm{mm} \mathrm{h}^{-1}\right)$; QD: Drainage rate, drainage $\left(\mathrm{mm} \mathrm{h}^{-1}\right)$.

\subsection{Determination of water requirements for swampland rice}

Water requirements for swampland rice are determined at three growth phases; early vegetative, reproductive, and ripening. Calculated by entering data on the coefficient of rice plants at the time of planting.
For rice production, the calculation of irrigation water during land preparation is based on the water necessary to replace water losses due to evaporation and percolation in paddy fields. The fields should be saturated during the land preparation for 30 days, with a water level of $250 \mathrm{~mm}$ or $8.33 \mathrm{~mm} /$ day. The van de Goor and Zijlstra formulation [6] was used to determine the amount of water needed.

IR: M.ek/(ek-1)

$\mathrm{IR}=$ water requirement in the paddy field ( $\mathrm{mm} /$ day).

$\mathrm{M}=1.1 \mathrm{ETo}+\mathrm{P}$ (mm/day), is the peak water requirement.

ETo $=$ evaporation $(\mathrm{mm} /$ day $)$.

$\mathrm{P}=$ percolation $(\mathrm{mm} /$ day $)$.

$\mathrm{k}=\mathrm{M} \cdot \mathrm{T} / \mathrm{S}$

$\mathrm{T}=$ time for land preparation (days).

$\mathrm{S}=$ water needs for fulfillment.

The percolation rate depends on the characteristics of the soil, namely the type of soil and its processing characteristics. Water percolation was provided during the growth of plants to clear the subsurface soil layer. The amount of percolation water ranges from 1 to $3 \mathrm{~mm} /$ day. In this study, percolation was determined at $2 \mathrm{~mm} /$ day. Water layer replacement was scheduled for 2 times as $50 \mathrm{~mm}$ of each, which is one and two months after transplantation [6].

Next, the consumption of consumptive water was calculated by multiplying the coefficient of rice plants by evapotranspiration. Then the water substitute layer (WLR) and the land preparation needs were calculated. The total amount of it was the value of plant water needs. Since planting in a different time, water needs are also different. The channel maintenance was calculated as $5 \%$ of the highest rainfall data.

Determination of the beginning of the growing seas on needs to consider the amount of rainfall needed for soil tillage and the initial phase of growth. The highest amount of water needed in one planting period is for soil tillage. Soil tillage takes 15-20 days with water requirements of 150-250 $\mathrm{mm}$ [7].

\subsection{Estimation of water balance in the field for MT 2019, 2020 and 2021}

Estimation of water balance was calculated based on the percent of water loss $(80 \%$ for dry years, $50 \%$ for normal years, and $20 \%$ for wet years) multiplied by the number of years then added with 1 [6].

\subsection{Determination of initial planting time}

Planting time was determined from the results of the water balance simulation with the beginning of the initial planting time which comply with the global planting plan in MT 2018. Then the results of the simulation were compared to the results of net rate estimation for MT 2018 to find out whether MT 2018 was a dry, normal, or wet year. The verified planting time of 2018 was used as a benchmark for simulating 
shift at the beginning of the planting season for MT 2019, 2020, and 2021. In another word, the planting time was simulated according to fluctuations in the early dry season shift resulted from the analys is of the MT 2018 water balance.

\section{Results and Discussion}

\subsection{Net water balance rate for the past $\mathbf{3 0}$ years}

Rainfall over the past 30 years shows fluctuations in rainwater runoff after being reduced by evapotranspiration. Information about when the dry season occurs and when the wet season can be seen clearly. Net rate with positive sign means a wet condition, while net rate with negative sign indicates a dry condition. Furthermore, this data will be used as a discourse for the selection of initial rice planting scenarios for the next 3 years (MT 2019-MT 2021) and also as a reference for setting the water level in the land.

The availability of groundwater, which is mostly derived from rainfall, is an important limiting factor for increasing crop production [8]. The analys is shows that the pattern of rainy and dry seasons in Banjarbaru City during the last 30 years has shifted every year. For the dry season, each year experienced a backward shift in the range of 1 to 30 days for 3 consecutive years, then advanced once in the range of 20 to 30 days, then a backward again of 1 to 10 days for 2 consecutive years. This can be interpreted as the initial hypothesis that shifting backward from 1 to 30 days occurred every year in MT 2019-2021.

\subsection{Rice crop water requirements}

In rice cultivation, there are three growth phases. Time duration, rice underwent a vegetative phase (beginning of healing until the formation of panicle/primordia), reproductive (primordia to flowering), and maturation (flowering until the grain is ripe) [9]. Water requirements in the three phases above vary, namely in the phase of active tillers formation, maximum tillers, panicle formation, pregnancy phases, and flowering phases.

The results of the calculation of water needs (10day basis or dasarian) to plant rice twice a year showed that the highest water demand for 2019 was predicted to occur in September in the second week of week III at $1,094 \mathrm{~mm} /$ day (Table 1). In 2020 the highest water demand of $1,112 \mathrm{~mm} /$ day occurred in October in the first week of week II (Table 2). In 2021 the highest water demand in the second week of October IV was at $1,112 \mathrm{~mm} /$ day (Table 3).

The need for water to replace the water layer (WLR) is determined according to the Directorate General of Water Resources [10]. The amount of water needed to replace the water layer was $50 \mathrm{~mm} /$ month (or $1.67 \mathrm{~mm} /$ day) within a month or two after transplantation. The amount of water needed for land preparation, based on the Directorate General of Water Resources [10] in irrigated areas is taken at $250 \mathrm{~mm}$ if the land has been left fallow for a period of fewer than 2.5 months.

Table 1. Prediction of rice crop water needs for MT 2019

\begin{tabular}{|c|c|c|c|}
\hline \multirow[t]{2}{*}{ MONTH } & \multirow{2}{*}{$\begin{array}{c}\text { Dasarian } \\
\text { (10 day basis) }\end{array}$} & \multicolumn{2}{|c|}{ Water Needs } \\
\hline & & $\mathrm{mm} / 10$ days & $\mathrm{mm} / \mathrm{day}$ \\
\hline \multirow[t]{3}{*}{ January } & 1 & 0.000 & 0.000 \\
\hline & 2 & 0.000 & 0.000 \\
\hline & 3 & 0.000 & 0.000 \\
\hline \multirow[t]{3}{*}{ Pebruary } & 1 & 0.000 & 0.000 \\
\hline & 2 & 0.000 & 0.000 \\
\hline & 3 & 0.000 & 0.000 \\
\hline \multirow[t]{3}{*}{ March } & 1 & 0.000 & 0.000 \\
\hline & 2 & 0.000 & 0.000 \\
\hline & 3 & 0.000 & 0.000 \\
\hline \multirow[t]{3}{*}{ April } & 1 & 0.000 & 0.000 \\
\hline & 2 & 0.000 & 0.000 \\
\hline & 3 & 1.974 & 0.197 \\
\hline \multirow[t]{3}{*}{ May } & 1 & 5.826 & 0.583 \\
\hline & 2 & 9.710 & 0.971 \\
\hline & 3 & 10.765 & 0.979 \\
\hline \multirow[t]{3}{*}{ June } & 1 & 8.660 & 0.866 \\
\hline & 2 & 6.824 & 0.682 \\
\hline & 3 & 6.183 & 0.618 \\
\hline \multirow[t]{3}{*}{ July } & 1 & 6.568 & 0.657 \\
\hline & 2 & 7.067 & 0.707 \\
\hline & 3 & 7.009 & 0.637 \\
\hline \multirow[t]{3}{*}{ August } & 1 & 6.947 & 0.695 \\
\hline & 2 & 6.348 & 0.635 \\
\hline & 3 & 6.890 & 0.626 \\
\hline \multirow[t]{3}{*}{ September } & 1 & 8.967 & 0.897 \\
\hline & 2 & 10.840 & 1.084 \\
\hline & 3 & 10.944 & 1.094 \\
\hline \multirow[t]{3}{*}{ October } & 1 & 9.431 & 0.943 \\
\hline & 2 & 7.738 & 0.774 \\
\hline & 3 & 7.170 & 0.652 \\
\hline \multirow[t]{3}{*}{ November } & 1 & 7.472 & 0.747 \\
\hline & 2 & 7.957 & 0.796 \\
\hline & 3 & 7.886 & 0.789 \\
\hline \multirow[t]{3}{*}{ December } & 1 & 7.049 & 0.705 \\
\hline & 2 & 6.493 & 0.649 \\
\hline & 3 & 5.031 & 0.457 \\
\hline
\end{tabular}

Table 2. Prediction of rice crop water needs for MT 2020

\begin{tabular}{|c|c|c|c|}
\hline \multirow[t]{2}{*}{ MONTH } & \multirow{2}{*}{$\begin{array}{l}\text { DASARIAN } \\
10 \text { Day Basis }\end{array}$} & \multicolumn{2}{|c|}{ Water Needs } \\
\hline & & $\mathrm{mm} / 10$ days & $\mathrm{mm} / \mathrm{day}$ \\
\hline \multirow[t]{3}{*}{ January } & 1 & 3.078 & 0.308 \\
\hline & 2 & 1.003 & 0.100 \\
\hline & 3 & 0.000 & 0.000 \\
\hline \multirow[t]{3}{*}{ February } & 1 & 0.000 & 0.000 \\
\hline & 2 & 0.000 & 0.000 \\
\hline & 3 & 0.000 & 0.000 \\
\hline \multirow[t]{3}{*}{ March } & 1 & 0.000 & 0.000 \\
\hline & 2 & 0.000 & 0.000 \\
\hline & 3 & 0.000 & 0.000 \\
\hline \multirow[t]{3}{*}{ April } & 1 & 0.000 & 0.000 \\
\hline & 2 & 0.000 & 0.000 \\
\hline & 3 & 0.000 & 0.000 \\
\hline \multirow[t]{3}{*}{ May } & 1 & 1.942 & 0.194 \\
\hline & 2 & 5.826 & 0.583 \\
\hline & 3 & 9.710 & 0.883 \\
\hline \multirow[t]{3}{*}{ June } & 1 & 10.496 & 1.050 \\
\hline & 2 & 8.660 & 0.866 \\
\hline & 3 & 6.824 & 0.682 \\
\hline \multirow[t]{3}{*}{ July } & 1 & 6.051 & 0.605 \\
\hline & 2 & 6.568 & 0.657 \\
\hline & 3 & 7.067 & 0.642 \\
\hline \multirow[t]{3}{*}{ August } & 1 & 7.524 & 0.752 \\
\hline & 2 & 6.947 & 0.695 \\
\hline & 3 & 6.348 & 0.577 \\
\hline \multirow[t]{3}{*}{ September } & 1 & 7.150 & 0.715 \\
\hline & 2 & 8.967 & 0.897 \\
\hline & 3 & 10.840 & 1.084 \\
\hline \multirow[t]{3}{*}{ October } & 1 & 11.123 & 1.112 \\
\hline & 2 & 9.431 & 0.943 \\
\hline & 3 & 7.738 & 0.703 \\
\hline \multirow[t]{3}{*}{ November } & 1 & 6.964 & 0.696 \\
\hline & 2 & 7.472 & 0.747 \\
\hline & 3 & 7.957 & 0.796 \\
\hline \multirow[t]{3}{*}{ December } & 1 & 7.627 & 0.763 \\
\hline & 2 & 7.049 & 0.705 \\
\hline & 3 & 6.493 & 0.590 \\
\hline
\end{tabular}


Table 3. Prediction of rice crop water needs for MT 2021

\begin{tabular}{|c|c|c|c|}
\hline \multirow[t]{2}{*}{ MONTH } & \multirow{2}{*}{$\begin{array}{l}\text { DASARIAN } \\
10 \text { Day Basis }\end{array}$} & \multicolumn{2}{|c|}{ Water Needs } \\
\hline & & $\mathrm{mm} / 10$ days & $\mathrm{mm} /$ day \\
\hline \multirow[t]{3}{*}{ January } & 1 & 5.209 & 0.521 \\
\hline & 2 & 3.078 & 0.308 \\
\hline & 3 & 1.003 & 0.091 \\
\hline \multirow[t]{3}{*}{ February } & 1 & 0.000 & 0.000 \\
\hline & 2 & 0.000 & 0.000 \\
\hline & 3 & 0.000 & 0.000 \\
\hline \multirow[t]{3}{*}{ March } & 1 & 0.000 & 0.000 \\
\hline & 2 & 0.000 & 0.000 \\
\hline & 3 & 0.000 & 0.000 \\
\hline \multirow[t]{3}{*}{ April } & 1 & 0.000 & 0.000 \\
\hline & 2 & 0.000 & 0.000 \\
\hline & 3 & 0.000 & 0.000 \\
\hline \multirow[t]{3}{*}{ May } & 1 & 0.000 & 0.000 \\
\hline & 2 & 1.942 & 0.194 \\
\hline & 3 & 5.826 & 0.530 \\
\hline \multirow[t]{3}{*}{ June } & 1 & 9.512 & 0.951 \\
\hline & 2 & 10.496 & 1.050 \\
\hline & 3 & 8.660 & 0.866 \\
\hline \multirow[t]{3}{*}{ Jule } & 1 & 6.701 & 0.670 \\
\hline & 2 & 6.051 & 0.605 \\
\hline & 3 & 6.568 & 0.597 \\
\hline \multirow[t]{3}{*}{ August } & 1 & 7.590 & 0.759 \\
\hline & 2 & 7.524 & 0.752 \\
\hline & 3 & 6.947 & 0.632 \\
\hline \multirow[t]{3}{*}{ September } & 1 & 6.635 & 0.664 \\
\hline & 2 & 7.150 & 0.715 \\
\hline & 3 & 8.967 & 0.897 \\
\hline \multirow[t]{3}{*}{ October } & 1 & 11.012 & 1.101 \\
\hline & 2 & 11.123 & 1.112 \\
\hline & 3 & 9.431 & 0.857 \\
\hline \multirow[t]{3}{*}{ November } & 1 & 7.547 & 0.755 \\
\hline & 2 & 6.964 & 0.696 \\
\hline & 3 & 7.472 & 0.747 \\
\hline \multirow[t]{3}{*}{ December } & 1 & 7.694 & 0.769 \\
\hline & 2 & 7.627 & 0.763 \\
\hline & 3 & 7.049 & 0.641 \\
\hline
\end{tabular}

\subsection{The initial scenario of rice planting}

This preliminary planting simulation uses a basis starting from MT 2019, then continued to MT 2021. The estimated net rate was included as a parameter of water availability for each year category such as rainy year, dry year, normal year, wet year.

The simulation results show that the most appropriate time to initiate rice planting for the 2019 MT period was May IV-June IV, and for the MT 2020 in June I-July I. MT 2021 is June II-July II. The timing of planting was chosen based on simulation results which showed a negative value which means the start of the dry season.

The initial MT determination criteria are the main key to provide accurate planting time recommendations. Plant growth and production are dynamic functions, non-linear interactions between weather, soil, food transport dynamics, and plant physiology per day so that they cannot be estimated based only on initial planting conditions where the average climate during the growing season [11]. Related to climate change, several climate change indicators that can be observed are rising air temperatures, changes in rainfall patterns, rising sea levels, and increasing extreme climate events. Also, local wis dom and natural signs such as prey structures are increasingly difficult to recognize and can no longer be used by the community [12].

Estimated net rates for 2019, 2020, and 2021 are categorized as dry years, normal years, and rainy years. Because it is calculated based on 30 years of data, the results can be cross-checked with the calculation of the net rate of 2019 as a reference point. BMKG 2019 stated that based on the results of calculations and analysis accompanied by consideration of physical conditions and atmospheric dynamics in the region of Indonesia and its surroundings, the forecast of the 2019 drought in Banjarbaru City occurred in May IV-June III with a comparison of the average rainfall for 30 years is the same. Besides, the shift in planting time, even though only about 10 days (dasarian), had the potential to reduce yields by up to $40 \%$ (Irianto 2000 in Wakhid et al. 2016). Various research results also indicated that the determination of planting time should accommodate the amount and distribution of rain and the requirements of a series of dry days to avoid drought during the planting period. These requirements need to be considered and used in the initial determination of the MT.
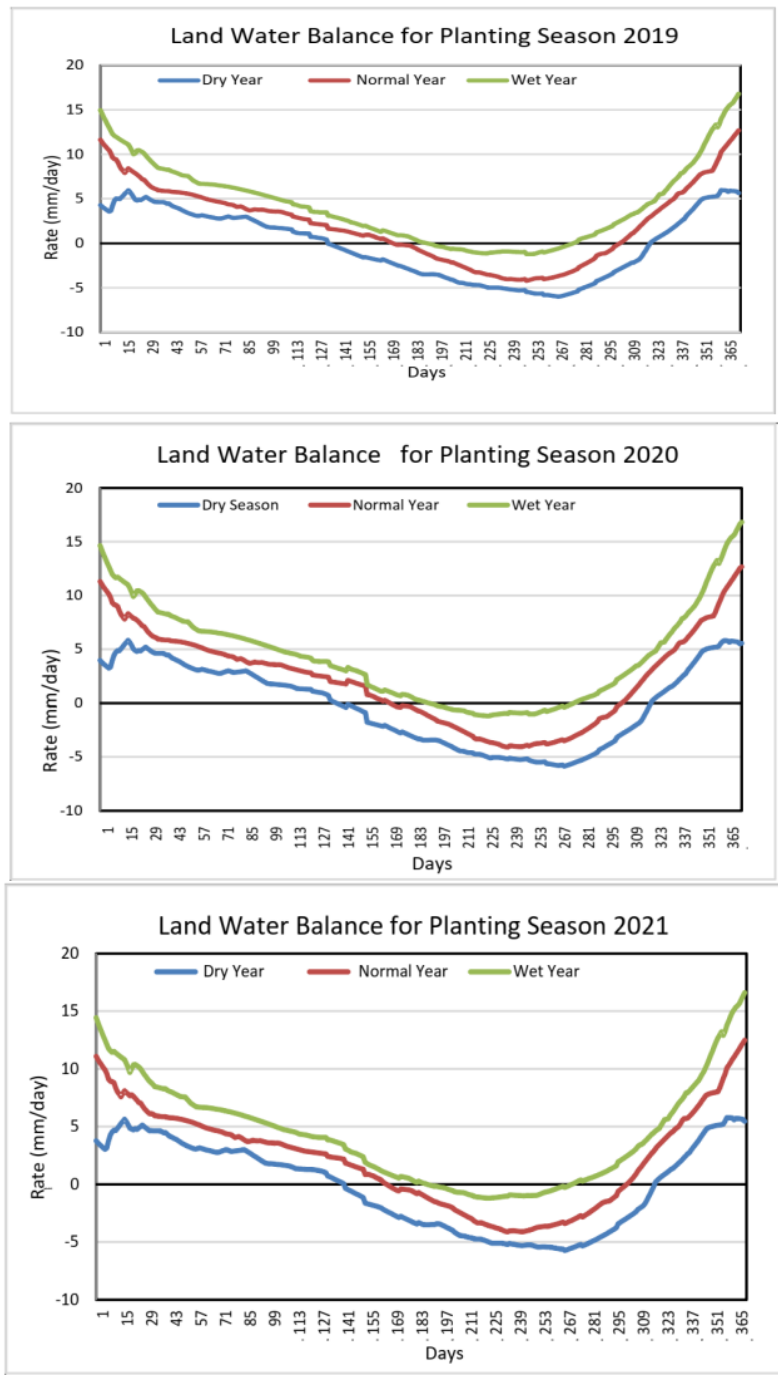

Figure 2. Water balance on MT 2019-2020. 


\section{Conclusion}

Based on the results of the analysis, it can be concluded that to predict the start of the swamp rice season, data components such as rainfall, temperature, and relative humidity are needed for 30 years. The year 2019 is the year of control of the analysis of the determination of the beginning of planting and the results were close to reality, so the components that exist in the simulation of water balance in the field can be used to predict the beginning of the planting season of the following year. The final results obtained based on this water balance simulation that the initial estimate of MT 2019 swamp rice planting was May IV-June IV, MT 2020 June I-July I, and MT 2021 is June II-July II. A pumping schedule is adjusted with data on water level results from recording equipment.

\section{Recommendation}

Measurement of water level in the land is highly required as a supporting factor for land water management so that the resulting product will be more optimal as well as a guideline in the preparation of land pumping schedules for drainage and irrigation.

\section{References}

1. E. Runtunuwu, H. Syahbuddin, and F. J. Agron. Indonesia 40 (1) : 8 - 14, (2012)

2. Stasiun Klimatologi Kelas I Banjarbaru, Bull. Prakiraan Musim Kemarau Di Kalimantan Selatan Tahun 2018, BMKG, Banjarbaru, (2018)

3. S. Ritung, E. Suryani, D. Subardja, Sukarman, K. Nugroho, Suparto, Hikmatullah, A. Mulyani, C.Tafakresnanto, Y. Sulaeman, R. E. Subandiono, Wahyunto, Ponidi, N. Prasodjo, U. Suryana, H. Hidayat, A. Priyono, and W. Supriatna, Sumber Daya Lahan Pertanian Indonesia Luas, Penyebaran, Dan Potensi Ketersediaan, IAARD PRESS, Jakarta, (2015)

4. M. Syakir and Dedi Nursyamsi., Kebijakan Pemerintah Dalam Pengembangan Lahan Sub Optimal Secara Produktif, Inklusif, dan Ekologis, in Prosiding Seminar Nasional Lahan Suboptimal Tahun 2015, PUR-PLSO,UNSRI, 8 - 9 October 2015, Palembang, Indonesia, (2015)

5. G. H. Hargreaves, and Z. A. Samani, J. Irrig. Drain. Eng., 108, 225-230, (1982)

6. Direktorat Irigasi dan Rawa, Standar Perencanaan Irigasi, Kriteria Perencanaan Bagian Perencanaan Jaringan Irigasi KP-01, Dirjen Sumber Daya Air, Kementerian PU, Jakarta, (2013)

7. Yoshida, Shouichi. Fundamental of Rice Crop Science. The International Rice Research Institute, Los Banos, the Philippine, (1981)

8. J.A.I. Paski, G.I.S.L. Faski, M.F. Handoyo, and D.A.S. Pertiwi, J. Ilmu Lingk., 15, 2, 83-89, (2017)

9. A.K. Makarim, dan E. Suhartatik. In. Publikasi Balai Besar Penelitian Tanaman Padi, 295-330, Badan Penelitian dan Pengembangan Pertanian,
Jakarta, (2009)

10. Direktorat Jenderal Pengairan, Pedoman perkiraan tersedianya air, Badan Penerbit Departemen PU, Jakarta, (2006)

11. E. Surmaini, and H. Syahbuddin, J. Litbang Pert., 35, 2, 47-56 (2016)

12. A. Pramudia, W. Estiningtyas, E. Susanti, and Suciantini, in Haryono, M. Sarwani, I. Las, and E. Pasandaran (eds.), Kalender Tanam Terpadu, 55100, IAARD Press, Jakarta, (2013) 